\title{
Democracy in America: \\ Labor Mobility, Ideology, and Constitutional Reform
}

\author{
Roger D . Congleton \\ Center for Study of Public Choice \\ G eorge Mason University \\ Fairfax, VA 22030
}

September 10, 2007

\begin{abstract}
Constitutional democracy in the United States emerged very gradually through a long series of constitutional bargains in the course of three centuries. No revolutions or revolutionary threats were necessary or evident during most of the three century-long transition to constitutional democracy in America. As in Europe, legislative authority gradually increased, wealth-based suffrage laws were gradually eliminated, the secret ballot was introduced, and the power of elected officials increased. For the most part, this occurred peacefully and lawfully, with few instances of open warfare or revolutionary threats. A theory of constitutional exchange grounded in rational choice models provides a good explanation for the distinctive features of American constitutional history, as it does for much of the West, although it does less well at explaining the timing of some changes.
\end{abstract}

\section{Introduction: The King and Council in Europe and America}

There is a sense in which all contemporary constitutional democracies can be regarded as revolutionary forms of government. Parliaments were commonplace throughout medieval E urope, but their members were for the most part members of elite families and served as a birthright or were appointed, rather than elected. The locus of policymaking authority was centered in a single royal man or woman and his or her appointed councilors. Prior to 1750, there were no national governments whose policymakers were elected on the basis of broad suffrage, and only a few city-sized governments with broad suffrage are found in historical records. O nly citizens, narrowly defined, could vote in Athens. O nly the wealthiest voted in medieval cities such as Sienna and Florence during their "republican" periods. O nly a small fraction of citizens could vote for the English House of Commons until well into the nineteenth century. 
Nonetheless, the shift to democratic governance in the West was rarely sudden, nor did it require a radical break with older institutions. Rather, new systems of governance emerged gradually during the eighteenth and nineteenth centuries as long-standing political institutions were revised a little at a time to take advantage of new political opportunities. Individual reforms of similar magnitude had occurred before, but this time a trend to the changes existed, rather than a random series of reforms and counter-reforms. At the end of this long series of more or less peaceful reforms, a completely new method of choosing parliaments emerged and a new assignment of policymaking power existed between the king and parliament.

The order and details of reforms differed among countries, but were generally driven by similar economic and ideological changes. For example, in Europe increased industrialization and shifts in ideology induced political authority to shift from kings to parliaments and also induced parliaments to became more broadly grounded in popular suffrage. This century-long shift in the locus of political power was a major event in European history, although the individual shifts of power and expansions of suffrage were often themselves relatively small events. Nor were these two shifts of policymaking power entirely connected. European parliaments had occasionally gained power in previous periods without broadening their electoral base, which before 1800 were generally limited to well-organized and well-born elites. In some cases, suffrage expanded more rapidly than power shifted to the parliament, as in G ermany; whereas in others, parliament became the dominant institution for public policymaking well before universal suffrage was obtained, as in England. Y et the democratic parliamentary governments of 1920 were broadly similar throughout western Europe and were radically different from the previous governments that Europe and the world had known in previous recorded history.

The transition to constitutional democracy in the United States differs somewhat from that of western Europe. There was another culture, the absence of an obvious king, a War of Independence, little formal aristocracy, and little industrialization at the time that political liberalization began. However, most of the difference is a matter of timing, rather than substance. The War of Independence may have played a role in America's mythology and a significant role in the emergence of national government; but it did not establish democracy in one fell swoop, as is often taught to grammar school students in the United States. Adult suffrage was not universal in the first decades after independence from England was won, 
although it was very broad by historical standards (Keyssar 2000). Moreover, the new constitution did not revolutionize governance, but rather adapted well-established colonial forms to national purposes. Those procedures were subsequently revised through formal and informal procedures of amendment by both central and state governments.

This paper provides a public choice perspective on the emergence of liberal democracy in the United States. Although the paper is motivated by rational choice models, there are no equations in this paper. The relevant mathematics has been developed in several previous papers, which characterize constitutional exchange and suffrage reform within divided governments. Those papers note that political authority is multidimensional and demonstrate that the tax veto power of parliament in combination with changes in political and economic circumstances (and uncertainty) can generate opportunities for mutually beneficial constitutional exchange among those with the authority to adopt reforms (Congleton 2001, 2007). The models also suggest that suffrage reform is substantially independent of the balance of authority between parliament and the king, and tends to be driven by changing suffrage norms and partisan interests, rather than changes in relative wealth or industrialization (Congleton 2004a). The purpose of this paper is to show that the same models that have previously been used to explain European and Japanese transitions to constitutional democracy (Congleton 2007, 2006, 2003, and 2001) also shed light on America's transition.

Constitutional bargains do not always favor parliament or liberalization, but can lead to agreements that gradually shift policymaking authority from the king (executive) to the parliament in favorable circumstances. The first half of America's transition to democracy took place in the century and a half before the D eclaration of Independence of 1776. The transition to parliamentary rule in the American colonies is surprisingly similar to that of Europe in the nineteenth century; although mobility and scarcity of labor, rather than industrialization, induced constitutional development in what subsequently became the United States. The second half of the transition took place during roughly the same period as in Europe and was, like that in Europe, catalyzed by changing interests associated with industrialization and the expanding influence of liberal ideology. (I use the term liberal in the European sense throughout the paper. The distinction between American and European usage is not important before 1900.) New economic and political interests created new 
opportunities for constitutional exchange, which in both Europe and North America led to constitutional democracy.

\section{Constitutional Competition in the Colonial Period}

Colonization of North America began nearly a century later than in South America, in large part because land rather than gold was the direct economic return for most investors in the North American colonies. Land does not automatically produce income or wealth. Land, unlike gold, is not portable and not valuable unless it is "improved" in some sense. Farming requires clearing and tilling. Mining requires exploration, digging, and smelting. Timber requires lumberjacks, saws, and sawmills. To profit from land holdings requires labor and capital in addition to land. Consequently, those who received large land grants or subsequently purchased large tracts in North America had a strong demand for labor and capital, because without those additional inputs, their large land holdings were essentially without value. Although many investors and land-grant recipients were nobles or members of noble families who had enough wealth to provide much of their own capital, they could not supply their own labor. Both skilled and unskilled labor had to be attracted to their colonies, towns, plantations, and farms if profits were to be realized from their investments in the North America. This demand for labor played a central role in the early constitutional developments of the English colonies of North America.

\section{Contracting Problems}

To attract labor and capital to their colonies, the landowners needed to assure labor, small businessmen, and other investors that they would be better off in their particular colony than at home. Landowners and ship owners sometimes made extravagant claims about colonial life to entice people to move to North America, as land developers do today; however, the most common method of attracting unskilled labor were loans made to workers to pay for their journey across the Atlantic and promises of support after arrival. Shipping agents and other entrepreneurs provided transportation to the colonies in exchange for promises of several years of labor, and those promises (contracts) were sold by shipping companies to landowners needing labor. These indentured servant contracts also normally promised workers a substantial piece of farmland after their transport loan had been worked off, which gave them an interest in adhering to the contract and also allowed the servants to become freemen after five to 10 years of hard work for their colonial masters. About half of the European emigrants 
to the colonies in the seventeenth and eighteenth centuries had their trips financed through indentured servant contracts ( $G$ alenson 1986). In some cases, however, promises were made and then reneged on after the "servants" arrived in America.

Such labor contracts were risky both for the indentured servant and the contract holder. O nce in America, indentured servants could not afford to purchase a ticket back to Europe if their master overstepped the bounds of the contract or reneged on his promise of land at the end of the contract period. Exit costs to other colonies were low, but not trivial, and in most places natural exit costs were reinforced by local laws. Conversely, masters might have difficulty with "runaways" whether they overstepped the bounds of the contract or not. Such problems would arise in part because of fraud on the part of laborers, but also as it became known that the promised land was not always delivered or of poorer quality than expected. In the early days, many servants also died from various diseases before paying off their debt.

Similar problems faced communities that attempted to attract tradesmen and the tradesmen who brought their skills or capital to the new colonies in exchange for promises of land or other support. People would be more willing to sign colonial contracts if the contract terms were reasonable and if subsequent promises and accumulated wealth would not be reneged on or expropriated. And, more people would provide such labor-backed loans if they were likely to be repaid.

In principle, such contracting problems can be solved through self-enforcing contracts, a well-functioning court system, or a combination of the two. However, in the early days, court systems did not always exist, and those that did tended to be biased in favor of major shareholders in the various companies charged with development and in favor of associates of the proprietors receiving the major land grants. D esigning self-enforcing contracts in circumstances in which time is an important element and courts are nonexistent or unreliable is clearly problematic. Indeed, the worst indentured contracts were such that they probably would not have been enforced in England, and the worst indentured contract owners (masters) might well have been punished for violating criminal law. Attracting labor to the New World required more reliable methods of enforcing contracts negotiated and signed in Europe and protection for other property and civil rights in North America.

Large landholders had a significant economic interest in developing methods for securing property rights and enforcing contracts in the colonies. If economic and political risks could be reduced for skilled and unskilled labor and for large and small capital investors, their land 
would become much more valuable. Institutional innovations that increased the effectiveness and perceived fairness of colonial political and legal institutions would increase the flow of labor and capital to particular colonies and thereby the wealth of large landholders. As in the case of the medieval tax constitution (Congleton 2007), a decision process that protected the landed gentry, capital owners, and labor from arbitrary treatment would advance the interests of all.

\section{The Virginia Experiment: Representative Political Institutions as a Means of Protecting Property Rights}

An institutional experiment based loosely on the English procedures was tried in the Virginia colony in 1619-21. The Virginia company replaced its authoritarian system of governance with a more representative one, which included: a governor, an appointed chamber, and an elected chamber. ${ }^{1}$

"THE one of which Councils, to be called THE COUNCIL OF STATE (and whose Office shall chiefly be assisting, with their Care, Advice, and Circumspection, to the said Governor) shall be chosen, nominated, placed and displaced, from time to time, by Us ..." [The other shall consist] "of two Burgesses out of every Town, Hundred, or other particular Plantation, to be respectively chosen by the Inhabitants: Which Council shall be called THE GENERAL ASSEMBLY, wherein (as also in the said Council of State) all Matters shall be decided, determined, and ordered, by the greater Part of the Voices then present; reserving to the G overnor always a Negative Voice. And this G eneral Assembly shall have free Power to treat, consult, and conclude, as well of all emergent Occasions concerning the Public Weal of the said Colony and every Part thereof, as also to make, ordain, and enact such general Laws and Orders, for the Behoof of the said Colony, and the good G overnment thereof." O rdinances for V irginia, July 24, 1621.

1 The second charter of the Virginia company was granted in 1609, two years after the colony was founded. Very extensive authority was granted to the company by the King for a period of 20 years in exchange for payments to the crown. The Virginia company's governing body was an appointed council, largely consisting of nobles, many of whom remained in England. The company council, in turn, delegated much of its authority to an appointed governor that made the voyage to the colony in Jamestown, Virginia.

A third charter was adopted in 1611, which gave the council significant legislative ability: "And shall likewise have full Power and Authority, to ordain and make such Laws and O rdinances, for the Good and Welfare of the said Plantation, as to them from Time to Time, shall be thought requisite and meet: So always, as the same be not contrary to the Laws and Statutes of this our Realm of England; And shall, in like Manner, have Power and Authority, to expulse, disfranchise, and put out of and from their said Company and Society for ever, all and every such Person and Persons." The ordinances for Virginia adopted in 1921 clearly laid out the new bicameral representative government for the colony itself. (Copies of the second and third charters and the 1621 ordinances are available from the Avalon Project at Yale Law School.) 
This template for governance solved many of the existing contracting and rulemaking problems.

The Virginia model provided the crown companies, proprietors, or crown with considerable control of the office of governor and the membership of the first chamber, which consequently represented the interest of well-connected major landholders and merchants. The second chamber was elected by town and country property holders and therefore represented the interests of the middle class. Together, the veto power of the two chambers protected the middle class and economic elites from each other and provided similar protections for the proprietors. Changes in basic contract law, property rights, and other civil liberties could be adopted only if they advanced the interests (of majorities) of all three groups. In this respect, the Virginia model provided fiscal and regulatory stability that was somewhat stronger than that noted by North and Weingast (1989) regarding England's parliament 70 years later (1689).

It was this institutional template together with the mobility of labor and the interests of large landowners that induced the emergence of relatively liberal forms of representative government throughout the North American colonies during the next century and a half.

\section{Gradual Liberalization of Colonial Governments}

Although the Virginia template gradually became the standard one for governance in the colonies, the other colonies also usually began with nondemocratic forms of government: a governor and unelected council of advisors. ${ }^{2}$ Initial variation in colonial governance was partly caused by cultural, economic, and religious differences. For example, Plymouth was a religious colony founded by Puritans, New Y ork was a commercial trading post founded by D utch merchants, and Maryland was a proprietorship (a colony initially purchased by a single person) that encouraged Catholic immigration. The Plymouth (1620), New Amsterdam (1624), and Maryland (1632) colonies all began with unelected governments and subsequently added elected chambers. This was also the case in West New Jersey, which was founded in 1664 and in North and South Carolina (initially a single colony) founded in 1664. Charter reforms were normally formally ratified in England in legal procedures initiated by colonial governors.

2 See Salmon and Cambell (1994, ch. 1) for an overview of Virginia's original authoritarian government. See Lutz (1998) for a collection of early colonial charters and codes. Many other colonial charters and ordinances are also available at Y ale Law School's A valon Project:

http:/ / www.yale.edu/ lawweb/ avalon/ avalon.htm. 
Within a few decades, colonial formeteurs found it useful to add elected chambers with veto power over taxes and laws in response to labor mobility and yardstick competition among the colonies. For example, in 1636 the Plymouth colony adopted a cabinet form of government with a governor and seven-person council of assistants elected by freemen. This was modified by adding provisions for equal protection of the law in 1641 and a bicameral legislature in 1644 (Massachusetts). Maryland adopted an elected assembly in 1638, equality before the law in 1638, and religious tolerance for all Christians in 1649. West New Jersey adopted a democratic bicameral government in 1681. Its elected chamber was called the General Free Assembly. New Amsterdam was taken from the Dutch by England and renamed New Y ork, but its religious liberties were continued and a new, relatively weak, representative assembly was adopted in 1683. (Similar assemblies had been proposed during the D utch period, but not adopted.) Connecticut secured a charter that provided for an elected governor and bicameral legislature in 1698 .

By 1700 a good deal of the architecture for democratic governance had already been worked out and broadly adopted in the colonies. Consider for example, these excerpts from the West New Jersey Charter of 1681 adopted nearly a decade before Locke finished his influential treatise on government and before England's G lorious Revolution. The excerpts are from Lutz (1998):

(i.) "There shall be a free assembly of the people for the Province aforesaid, yearly and every year at a day certain chosen by the said free people of said province, whereupon all of the representatives of the free people of the said Province shall be summoned to appear ... to make and ordain such acts as shall be requisite for good government and prosperity of the free people of said province ..."

(ii.) "The Governor of said province shall not suspend or delay the signing, sealing and confirming of such laws as the $G$ eneral Assembly shall make..." (iii.) "That it shall not be lawful for the Governor to make or enact any law or laws for said Province without the consent, act, and concurrence of the General Free Assembly..."

(iv.) "That it shall not be lawful for the Governor and council, or any of them, to levy taxes without the consent, act, and concurrence of the General Free Assembly ... " (v.) "That no General Free Assembly shall give to the Governor, his heirs, or successors any tax or custom for any time longer than one whole year." 
Although the North American colonies were often founded for profit and often run by chartered companies, they turned out to be great experimental laboratories of governance. Indeed, the freedom to conduct constitutional experiments could be counted as one of the great unexpected consequences of the discovery of the New World, perhaps the greatest in the long run.

\section{The Power of the Purse, Labor Mobility, and Constitutional}

\section{Liberalization}

Colonial governors and their governments were not as powerful in the North American colonies as in medieval Europe or as centralized as in the South American colonies. This was partly because the North American colonies were less profitable than colonies elsewhere and so were less directly supported by well-organized European armies, courts, and police. With little or no standing tax revenues and with little support from English taxpayers or crown companies, the royal colonial governors were very dependent on their legislatures for revenues and often for their salaries. G overnors needed reliable majorities in the colonial parliaments to secure the resources for governing, which made the governors very dependent on their colonial legislatures and also provided them with good reason to look for additional revenue from the British parliament. It also made the colonial parliaments among the most powerful representative assemblies in the world at the time, in terms of their control over legislation and taxation. ${ }^{3}$

The power of government was also constrained by the desire to attract new residents (e.g., the demand for labor). Migration to and among the colonies was catalyzed by the efforts of entrepreneurs in Europe and the colonies. Colonial governments, which often represented investor interests, also attempted to attract the resources necessary for viability and company profits. In the North, religious leaders organized groups to found new settlements to promote narrow religious practices, although these leaders also recognized the need for additional colonists to increase the viability of their communities and "spread the word." Land speculators aggressively sought labor and capital to increase the value of their land holdings. Without relatively liberal political institutions, a colony's landed gentry might have a bit more political power and "their" people might exhibit greater cultural uniformity, but they would

3 The governor of the Connecticut and Rhode Island colonies were (indirectly) elected by the colonists. O ther governors held office through royal appointment or were appointed by colonial companies and proprietors. 
have been less wealthy and more at risk, because there would be fewer persons to farm, timber, mine, manage, purchase, and protect their land holdings.

A poor or overly repressive colony or community was relatively easy to exit, because. decentralized governance made it relatively easy to move to other towns and colonies with somewhat different rules and rulers. ${ }^{4}$ Many of the colonies were physically close together, because they were relatively small - as in the North with Massachusetts, Rhode Island, and Connecticut- and/ or were linked together by common waterways - as with Maryland, Virginia, and Pennsylvania or New Jersey and New Y ork. Ships ran up and down the coast of North America, and the same rivers that allowed commerce to develop inland from the coast also allowed pioneers to move from town to town. Less liberalization was evident in the Southem colonies, in part because they were less dependent on free labor. Wealth requirements for suffrage and office, for example, were somewhat higher. ${ }^{6}$

4 The possibility of exit must also have moderated the behavior of other colonial governments around the world with respect to their immigrants as well. But many were more profitable than the North American colonies and, thus, they were better policed and exit costs could be driven higher by local governments. European diseases had also greatly reduced the native "Indian" population, which simultaneously increased the demand for colonists and provided many more opportunities for resettlement (more open land) than in many other parts of the world.

5 The North A merican colonies were independently organized and governed, rather than centrally administered under the tight control of England. This was partly a matter of luck. The seventeenthcentury in England was a period of political turmoil, involving a major civil war, Cromwell's dictatorship, a restoration, and a G lorious Revolution. It was not until the decade before the Glorious Revolution that the crown (James II) began centralizing governance in the colonies. He initiated a series of lawsuits to revoke colonial charters. His success in court allowed him to issue the D ominion of N ew E ngland in 1685, which eventually placed all of New England, New Y ork, and New Jersey under a single authoritarian administration. James II appointed a single man to rule the D ominion. G overnor Andros, as ordered, restricted local assemblies throughout the D ominion and reduced judicial independence by appointing new judges and suspending the Massachusetts $G$ eneral Court. New taxes were imposed, and existing land claims were challenged. Enforcement of the Navigation Acts was stepped up. Writs against the charters of Maryland, the Carolinas, Pennsylvania, and the Bahamas were pending. If successful, the D ominion would clearly have greatly reduced political autonomy throughout the English colonies in North America (Taylor 2001: 276-77; Haffenden 1958; O sgood 1902). This policy of centralization ended for several decades in 1689, when William III and the Dutch army induced James II to flee the thrown. William reinstated several colonial charters and, with them, decentralized governance in the colonies. G eorge III was the next monarch to attempt to centralize control in the North American colonies, which more or less directly induced the War of Independence.

6 European political institutions also evolved to increase the value of land, but in a situation in which labor was not often scarce, given Malthusian labor supplies. Competition for free labor was generally far less intense in Europe, because the supply of labor was relatively larger and its marginal productivity was lower. However, there are several cases in which individual European monarchs encouraged immigration of relatively highly skilled groups that could produce services unavailable locally. Immigration was often encouraged with subsidies and by granting special civil and political liberties within specific communities or "free towns." 
By assuring stable property rights and allowing provision of needed public services, representative political institutions tended to increase prosperity, a prosperity that tended to be reinforced by subsequent inflows of labor and capital. A good deal of the population growth was simply the effect of learning to farm in the New World and, consequently, increased rates of survival and family size. But much of the commercial prosperity can be attributed to the relatively rapid improvement in governance and government services. The latter was often simply the rule of law and absence of impediments to trade (low exit costs) - which contemporary research shows tends to increase economic growth (G wartney, Lawson, and Holcombe 2006) - however, the quality of government policies doubtless also played a role (Keefer and Knack 1995, Congleton 2007b). ${ }^{7}$ The success of such relatively democratic institutions was evident in the emigration rates, use of new labor contracts, and economic growth. Major commercial centers emerged along the Eastern seaboard at Boston, New York, Philadelphia, and Charleston. Population and economic development increased rapidly during the seventeenth century, and by century's end the larger colonies were comparable in size to the smaller European states in 1700.

Figure 1: European Derived Population of the Five Largest Colonies (1640-1780)

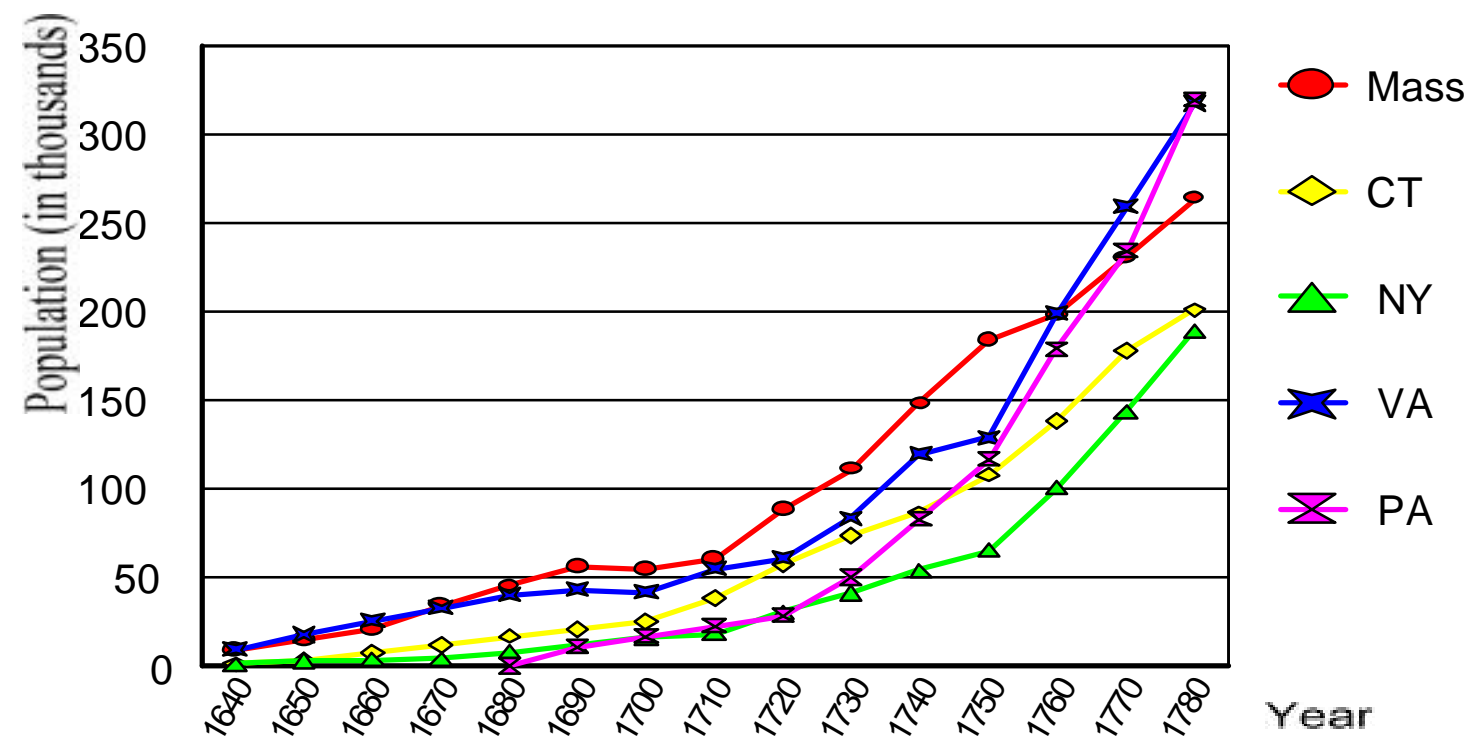

The colonial governments that emerged in the course of a century of competition, bargaining, and experimentation were relatively liberal and democratic versions of the English

7 It is interesting to note that many of the contemporary indexes of "institutional quality" can also be used as indices of the "liberalness" of a polity's political and economic institutions. 
political template. As in England, the colonial governments typically included bicameral legislatures with one elected and one appointed chamber, each with veto power over new taxes and new laws. In the colonies, the appointed chamber was often an elite chamber composed of senior government officials and major landholders and thus were analogous to the noble chambers of European parliaments in that era, although membership was not entirely based on family bloodlines. The elected second chamber was generally elected on the basis of much broader suffrage than in European parliaments. The suffrage base of the lower chamber tended to increase as the number of freemen increased through time, although suffrage laws were occasionally tightened. Rather than 5 or 10 percent male suffrage, as was common in Europe until the nineteenth century, colonial suffrage was often greater than 50 percent and occasionally close to 100 percent of adult males, because so many families owned their own land and so met minimum property requirements (particularly in the northern and mid-A tlantic colonies). This was a breadth of suffrage not reached in Europe until late in the nineteenth century, a century and a half later. Electoral politics, consequently, became mass marketing affairs in the North A tlantic colonies well before it did in Europe (in local and regional newspapers and pamphlets).

The combination of parliamentary authority and broad suffrage demonstrate that colonial governments were well on their way to becoming parliamentary democracies well before independence was declared in 1776 . The association between democratic bicameral forms of the "king and council" template and prosperity led essentially all of the North American colonies to adopt them during the late seventeenth and early eighteenth centuries. ${ }^{8}$ This is not to say that the colonies were modern liberal states, but rather that, by the standards of world history, colonial governments were relatively liberal and democratic. Religious freedoms in the northern colonies, for example, were often as limited as in Europe. In Massachusetts, Catholic priests were subject to lifetime imprisonment. Even in relatively tolerant states, suffrage and the right to hold elective office were often limited by religion as well as wealth (Fiske 1888: 76).

\section{Independence and Democratic Constitutions for the United States}

The D eclaration of Independence and subsequent war to secede from the British Empire provided new opportunities for constitutional bargaining, experimentation, and exchange.

8 By the time of the Revolutionary War, only Pennsylvania had a purely unicameral legislature, although it too had briefly experimented with the Virginia model. 
There were new problems to address and important veto players disappeared. These created numerous opportunities for constitutional exchange among those with the authority to amend existing arrangements. The resulting constitutional bargains created the first sizable polities grounded entirely in broad suffrage.

\section{Independence and the Selection of New "Colonial" Governors}

The Declaration of Independence had immediate and direct effects on the organization of the executive branch at the state level. The royal and proprietary governors who had run the executive, albeit subject to considerable control by elected colonial parliaments, lost their offices. The remaining parts of government could have dispensed with the executive office, but organizational conservatism and the advantages of executive administration prevailed, and governors were replaced, rather than the office eliminated.

Two methods for selecting governors attracted the most attention within colonial legislatures, and both were used by subsets of the new sovereign state governments. G overnors could be indirectly selected by elected state legislatures, or governors could be selected directly by state electorates. Parliamentary appointment is consistent with a self-interest theory of constitutional reform, because this maximizes the parliament's control of the executive. Those favoring the direct election of governors focused on partisan advantage and a mixture of ideological and historical concerns over unified governance. Leaders of majority coalitions that expected to win elections for governor had reason to favor directly elected governors, because independent elections would tend to provide them with a relatively more powerful office than that of prime minister. Direct election of governors also tended to be supported by normative theories of governance (ideology) that were widely accepted within colonial elites and also by those fearful of what Paine termed the "vices of government."

In the next few years, finely grained constitutional bargains were struck among idealists and pragmatists (and those in between) within the pre-existing colonial legislatures, and later various states adopted what would be termed "prime ministerial" and "presidential" systems. Most states chose a prime ministerial system of governance. In only three cases did a majority of the legislature initially favor direct election of governors. ${ }^{9}$ This is not to say that ideological considerations were not evident. Most state constitutions were explicitly grounded in popular

9 After 1780 several state constitutions were modified to include independently elected governors. New Hampshire did so in 1783, Pennsylvania in 1790, and D elaware in 1792 (Fiske 1888, pp. 67-68). 
sovereignty theories of government. Most of the new state constitutions also included lists of rights. Most included provisions for broad male suffrage subject to wealth or tax constraints, although in some cases suffrage was also limited by religion and race. No new constitution mentions a state-supported church, although the degree of constitutional protection for freedom of worship varied among the states. Some constitutions only protected open worship by Protestants (North and South Carolina) and others by Christians (Maryland). Complete freedom of religious conscience was assured by the state constitutions of $\mathrm{G}$ eorgia, Massachusetts, New Jersey, New Y ork, Pennsylvania, Virginia, and Vermont. Many state constitutions also explicitly forbade clergy from holding state offices. O nly D elaware's constitution explicitly rules out the establishment of a state church. ${ }^{10}$

\begin{tabular}{|c|c|c|c|c|c|c|c|}
\hline \multicolumn{8}{|c|}{$\begin{array}{r}\text { Table } 1 \\
\text { Characteristics of New State Constitu }\end{array}$} \\
\hline & Date & $\begin{array}{l}\text { Election of } \\
\text { Governor }\end{array}$ & Legislature & $\begin{array}{l}\text { Freeman } \\
\text { Definition }^{10}\end{array}$ & $\begin{array}{l}\text { List of } \\
\text { Rights }\end{array}$ & $\begin{array}{l}\text { Supreme } \\
\text { Court }\end{array}$ & $\begin{array}{l}\text { State } \\
\text { Church }\end{array}$ \\
\hline Delaware & 1776 & Legislature & Bicameral & retained & yes & yes & no \\
\hline Georgia & 1777 & Legislature & Unicamera $^{3}$ & 10 pounds $^{4}$ & yes & yes & no \\
\hline Maryland & 1776 & Legislature & Bicameral & 50 acres & yes & yes & no $^{1}$ \\
\hline Massachusetts & 1780 & Freemen & Bicameral & 60 pounds & yes & no & no \\
\hline New Hampshire & 1776 & Legislature & Unicamera $^{3}$ & retained & no & no & no \\
\hline New Jersey & 1776 & Legislature & Bicameral & 50 pounds $^{2}$ & yes & yes & no \\
\hline New York & 1777 & Freemen & Bicameral & 100 pounds $^{8}$ & yes & yes & no \\
\hline North Carolina & 1776 & Legislature & Bicameral & 50 acres $^{5}$ & yes & yes & no \\
\hline Pennsylvania & 1776 & Legislature & Unicamera $^{3}$ & paid taxes & yes & yes & no \\
\hline South Carolina & 1778 & Legislature & Bicameral & 50 acres $^{6}$ & yes & no & no $^{9}$ \\
\hline Vermont $^{7}$ & 1777 & Freemen & Bicameral & all men & yes & yes & no \\
\hline Virginia & 1776 & Legislature & Bicameral & retained & yes & yes & no \\
\hline \multicolumn{8}{|c|}{$\begin{array}{l}{ }^{1} \text { Article } 33 \text { allows the possibility of supporting Christian churches using tax revenue. } \\
{ }^{2} \text { Article } 4 \text { says that "all inhabitants of this Colony, of full age, who are worth fifty pounds proclamation money" may } \\
\text { vote. This gave independent women the right to vote until the wording was changed two decades later (Keyssar 2000, } \\
\text { p. } 54 \text { ). }\end{array}$} \\
\hline
\end{tabular}

10 Two colonies did not face an urgent requirement to rewrite their colonial constitutions, because their charters had longed called for indirectly elected governors, Connecticut (1662) and Rhode Island (1663). Connecticut continued to be governed under its colonial charter until 1818. Rhode Island continued to use its colonial charter as its state constitution until 1843. 


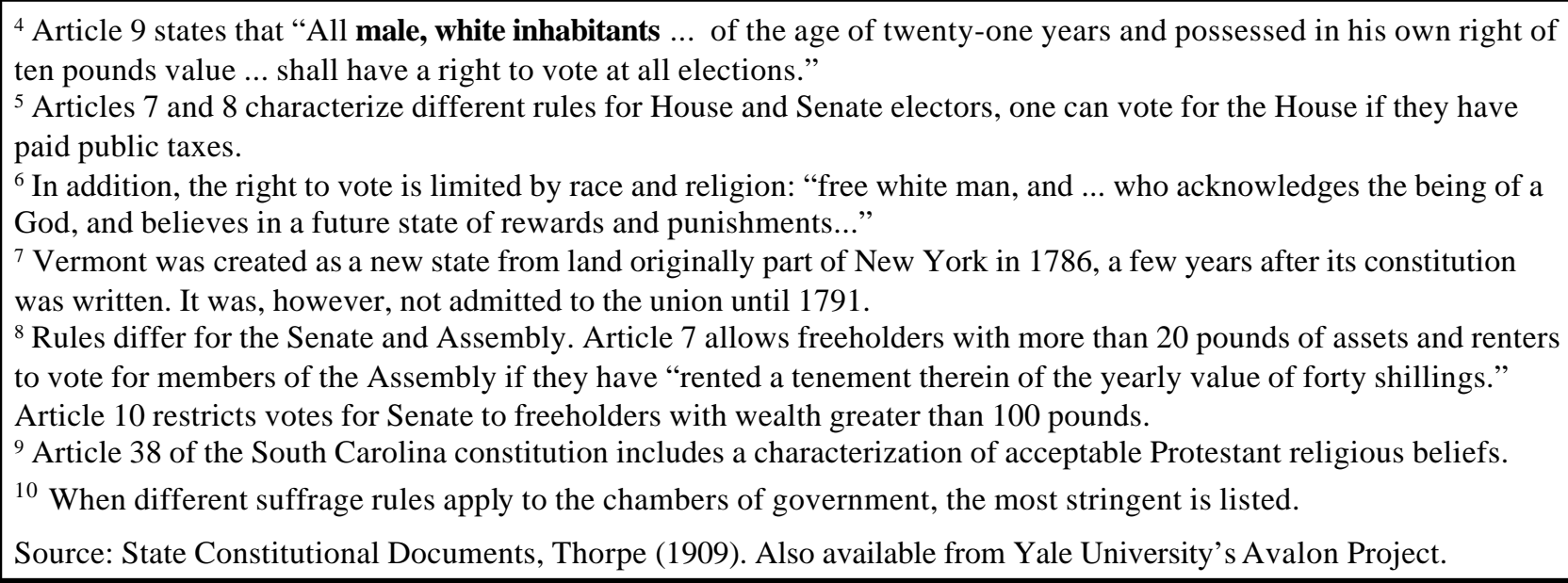

\section{State Sovereignty and National Governance}

Before independence, an alliance of the colony-states was formed to coordinate and share the cost of lobbying the British Crown and Parliament. After independence was declared, the alliance was formalized as a treaty organization of sovereign states, somewhat analogous to the old D utch Republic and modern European Union. ${ }^{11}$ This first national government was formalized and extended by the Articles of Confederation, which were completed in 1777 and used for the next two decades, although they was not ratified by all member states until 1781. The new treaty organization had to be acceptable to all member states and consequently established a relatively weak central government that was essentially a coordinating body with no authority to impose taxes and little ability to impose other rules on its members. ${ }^{12}$

11 Articles two and three clearly indicate that the confederation addresses common defense concerns and preserves state sovereignty. "(II) Each state retains its sovereignty, freedom, and independence, and every power, jurisdiction, and right, which is not by this Confederation expressly delegated to the United States, in Congress assembled. (III) The said States hereby severally enter into a firm league of friendship with each other, for their common defense, the security of their liberties, and their mutual and general welfare, binding themselves to assist each other, against all force offered to, or attacks made upon them, or any of them, on account of religion, sovereignty, trade, or any other pretense whatever."

However, Article 13 suggests that the articles are intended to create an organization that is more durable and powerful than the usual treaty organization: "Every State shall abide by the determination of the United States in Congress assembled, on all questions which by this confederation are submitted to them. And the Articles of this Confederation shall be inviolably observed by every State, and the Union shall be perpetual; nor shall any alteration at any time hereafter be made in any of them; unless such alteration be agreed to in a Congress of the United States, and be afterwards confirmed by the legislatures of every State."

12 See Congleton (2004b) and Congleton, Kyriacou, and Bacaria (2003) for rational choice-based theories of voluntary association among state governments, as within treaty organizations. 
Governance under the Articles of Confederation proved adequate for a time of war, and was able to pass significant legislation, such as the Northwest O rdinance governing the admission of new states. However, it was widely regarded, perhaps surprisingly, as too weak to advance national interests during the time of peace after the war was won in 1783. States ignored requests for contributions to the central government, trade barriers were being erected among the states, conflicts about the location of state boundaries were left unresolved, and national defense was poorly financed and orchestrated. Secession from the confederation was being discussed (Fiske 1888: ch. 4).

A prominent group of state and national politicians believed that a stronger central government would be necessary if the United States were to survive. Negotiations for a stronger constitution took place in assemblies of appointed state representatives in Annapolis and Philadelphia, many of whom had recently participated in drafting their state constitutions. The national Congress accepted the recommended reforms without comment and the results were sent to state governments for ratification or rejection in 1787. After much public debate, the proposed constitution was approved by all of the member states in 1790. In this manner, a weak central government was peacefully and lawfully transformed into a far stronger one.

The new Constitution substantially modified the pre-existing Congress of appointed state representatives with a rotating presidency. The new Constitution added a directly elected chamber, a national court, and greatly strengthened the presidency. One chamber of the new parliament essentially preserved the original Congress of state representatives, which helped obtain the approval of the smaller states: the Senate consisted of two representatives appointed by each member-state government. A completely new directly elected chamber was a added to the central government, the House of Representatives. Its members were directly elected by voters in single member districts (based on population) and had essentially the same powers as the Senate. The rotating presidency of the old Congress was replaced by a new, more powerful indirectly elected president, who also had veto power and would execute the laws approved by both assemblies and serve as commander in chief in times of war. ${ }^{13}$

The normative basis of the new national constitution was grounded in Enlightenment theories of popular sovereignty, rather than the divine right of kings, the military power of

${ }_{13}$ It is easy to exaggerate how centralized the new government really was. For the next century and a half, the main source of government services remained local (town and counties) rather than federal. It was not until approximately 1935, after the progressive amendments (see below), that federal expenditures exceeded state and local expenditures. See $\mathrm{H}$ istorical Statistics of the U nited States Volume 5, 2006: Table Ea-A, pp. 5-6. 
formeteurs, or long-standing informal and unwritten practices, as was also true of the previously adopted state constitutions. Those drafting the constitution sought an encompassing authority, but drew it from the "self-evident" rights of man, rather than historic precedent or biblical citations, as might have been expected from the representatives of a deeply religious society. ${ }^{14}$ The Constitution of the United States begins with the words "We the people."

Although it was not a radical experiment, the new national constitution was a significant event in the history of liberal democracy. It created the first government of a large territory that was completely grounded in elections with broad suffrage. It included a bill of rights that would be supported by an independent Supreme Court. ${ }^{15}$ Its federal structure was scalable and was subsequently extended to govern a far larger territory simply by creating new states. In the next few decades, the representative democratic government of the United States demonstrated that rule of law could be implemented by popular government and that more or less moderate policies could be adopted by governments based on relatively broad suffrage. Wealth was not taken from the rich, huge deficits were not run, and law and order was not completely undermined by officials directly or indirectly selected by common persons.

The success of this relatively democratic national government supported nineteenthcentury arguments in Europe about the feasibility of popular government. Such governments had previously been intangible speculations of political philosophers or quite unusual forms of city government studied by political historians. If the liberal political institutions of the United States functioned reasonably well, perhaps the political ideas of the English levelers, Locke, Montesquieu, and Rousseau were not impossible pipe dreams of idealists and scholars. Perhaps, such ideas could provide an intellectual foundation for practical alternatives to existing arrangements in Europe. ${ }^{16}$

14 See Miller (1991) for a discussion of the shift from traditionalist and religious theories of democracy and community to liberal ones in eighteenth century America.

15 Several of the state assemblies and state constitutional conventions approved the Constitution, subject to the addition of a "bill of rights" that more clearly characterized the bounds of central government authority, as already found in most state constitutions. Twelve amendments were adopted in rapid succession by the Congress to satisfy this demand. Ten amendments (the Bill of Rights) were approved by Congress, the President, and the requisite number of state legislatures in D ecember 15, 1791. (Two of the original twelve amendments passed by Congress did not receive sufficient state support to be adopted.) The first ten amendments are essentially part of the original constitution.

16 The point here is not that the new government inspired the rise of European democracy in the nineteenth century, but rather that the U. S. Constitution played a significant role in subsequent political debate and reform in Europe by providing evidence that relatively peaceful transitions to 


\section{Constitutional Reform in the New Republic, 1792-1870}

Constitutional reforms continued throughout the next century and a half, which gradually transformed a relatively liberal representative system into a more completely democratic one. The Constitution was formally amended more than a dozen times and informally amended many more times. New territories were acquired, organized, and admitted as states to the Union. State governments were reorganized, as governors became independently elected offices with broader powers and elected second chambers were added (Benjamin 1985, Fiske 1888). The balance of policymaking authority within the central government and between the central government and the states was continually debated and adjusted at the margin. Suffrage laws were reformed at both state and national levels. The power of the Supreme Court was increased early in the nineteenth century through its own decisions (Rhenquist 2001: ch. 1). Bargaining over formal constitutional reforms as well as quasi-constitutional ones were nearly continuous throughout the nineteenth century, as was also true in Europe. Although the constitution was sufficiently stable to serve as "rules for making rules," neither the process of adopting new laws nor the constraints on laws that could be adopted were chiseled in stone.

Consistent with the models previously developed, the bargains struck reflected changing economic interests, ideology, and preexisting institutions. Unfortunately, in addition to the political effects of early industrialization, liberal ideology, and the inclusion of new states, a problem postponed during the constitutional deliberations of 1787 led to a constitutional crisis and another war of succession in the middle of the nineteenth century. In this case, however, those attempting to secede lost the war, albeit at great cost to both sides.

\section{Perpetual Union or State Sovereignty?}

Under the Constitution, slavery was a state regulatory issue, and support for or against this ancient institution varied by region, because of the balance of ideological and economic interests. In the northern states, where slavery was economically unimportant, abolitionists pressed for its elimination, and slavery was gradually abolished beginning with D elaware in

representative governance could be undertaken, in contrast with the evidence generated by the French Revolution. See, for example, Mclean (2004) for a discussion of effects of American political theory on the French Revolution. Thomas Paine, quoted below, also provided intellectual support for the French Revolution where he was charged with treason (as he had previously been by England). Numerous constitutional documents and laws were translated and discussed throughout Europe. 
1776, Vermont in 1777, Pennsylvania in 1780, and Massachusetts in 1780. In the South, where slavery was economically important (for tobacco, rice, indigo, and subsequently cotton production), slavery was retained despite the efforts of Southern abolitionists. Abolition of slavery throughout the United States became an increasingly important ideological issue in Northern elections and consequently within the House of Representatives where representation was determined by state population.

In 1860, fearing that the national government would adopt new liberal laws on slavery (which was not likely given the balance in the Senate) and other laws such as tariffs that reduced their wealth, the Southern states attempted to secede from the union. The constitutionality of secession was much debated in the period leading up to the war (Farber 2003: chs. 4-5). Articles 2 and 3 of the Articles of Confederation had explicitly guaranteed state sovereignty on all matters not transferred to the Congress, although Article 13 had committed signatory states to a "perpetual union." The legal and philosophical tension between perpetual union and state sovereignty, however, was not peacefully resolved through constitutional bargaining. Rather, the perpetual union agreed to under Article 13 was preserved by force of arms in the Civil War (1860-65). According to Lincoln's interpretation of the Constitution, sovereign states did not have the right to secede from a perpetual union.

\section{Suffrage and the Civil War}

Suffrage law during the colonial period had been based on property holdings with further restrictions based on civic status (free or slave), residency, race, and literacy. Who was or was not sufficiently independent (a freeholder) to cast a meaningful vote differed among the colonies (and states) through time, both before and after independence. After independence, suffrage remained a state matter, and was gradually expanded in the early nineteenth century as the definition of "freeholder" was liberalized and wealth requirements reduced. This was partly a result of interstate competition for labor, as the new states often had more liberal rules than the original colonies. It was also partly a consequence of changing norms and expanding public education, as in Europe. More and more persons were deemed to be sufficiently independent and knowledgeable to participate in elections. This shifting ideological consensus is clearly evident in the Fifteenth Amendment to the national constitution passed after the Civil War. 
The Constitution was amended three times after the conclusion of the Civil War. This was possible because of the prior secession of the Southern states and the military success of the Northern states, which jointly produced a temporary exclusion of the Southern states from self-governance and from the federal amendment process. A supermajority of the seats in the Civil War Congress were temporarily occupied by Northern liberals and abolitionists. As a consequence, three amendments were negotiated, adopted, and ratified by the states that remained in the Union. The Thirteenth Amendment (1865) made slavery illegal ${ }^{17}$; the Fourteenth Amendment (1868) defined citizenship in inclusive terms (all persons born or naturalized in the United States) and guaranteed equal protection of the law to all citizens; and the Fifteenth Amendment (1870) ruled out state laws that used race or color as a condition of suffrage. In this manner, slavery was ended in the South, and freed slaves became eligible to vote in federal elections. O ther previously excluded persons in the Northern states also received the right to vote and expanded legal protections.

These were civil liberty reforms that were largely motivated by liberal ideological concerns (the civic equality of all citizens), although they also advanced the short-term political interests of the Republican Party, for whom the newly enfranchised were expected to vote. The Southern states had to accept the amendments to regain self-governance, and all subsequently ratified these amendments. After control over policy was returned to Southern state governments, however, suffrage laws gradually became more restrictive, as various literacy tests and fees (poll taxes) for voters were introduced to exclude former slaves and many other poor persons from voting (Keyssar 2000). There was clearly no slippery slope to universal male suffrage in the South. ${ }^{18}$

17 Slavery had been eliminated in most of Europe several decades earlier, as it had been in the Northern states. It bears noting, however, that Southern slave owners were not compensated for their capital losses as they were in many European countries. Slaves accounted for about half of Southern wealth in 1860.

18 The 15th amendment did not create universal male suffrage, but eliminated race as a consideration in who could lawfully cast votes in national elections. O ther criteria could still be applied, for example, wealth, literacy, and payment of taxes. (This overturned parts of some Southern state constitutions and in this sense could be said to increase central government authority over the states.) Poll taxes used in eight states, rigged literacy tests, and KKK terrorism also reduced suffrage significantly both within working class and black communities. (It bears noting that, perhaps as a consequence of the interests actually represented in government, the South industrialized far more slowly than the North, and had slower income growth. After suffrage was expanded in the late 1960s, per capita income in the Southern states began catching up with the rest of the country.) 
Although the Civil War, like the Revolutionary War, attracts considerable attention among historians and plays an important role in American political mythology, it was by no means the only significant constitutional event of the nineteenth and early twentieth centuries. Indeed, the war itself and its three associated amendments had a smaller effect on peacetime national governance and public policy than many Progressive reforms and amendments adopted in the half century after the war's end.

\section{A Digression on Economic and Ideological Developments in the Nineteenth Century}

There was no equivalent to the Civil War in Europe, but many other features of the evolution of constitutional democracy in the United States paralleled developments in Europe. ${ }^{19}$ The political and economic trends of the nineteenth century were direct and indirect consequences of improved farming, industrialization, and urbanization and shifts in political ideology. Ideological change was somewhat less evident in the United States than in Europe, because there were very few "true" conservatives in the European sense. The center of gravity of American politics had been liberal for a century in the sense used here, well before the term was first applied to politics. The medieval order had few proponents in the United States. ${ }^{20}$

\section{Economic Development: Industrialization and Urbanization}

As in Europe, North American society was undergoing a major transformation for the first time in 10,000 years, when settled agriculture was being worked out. Both ordinary life

19 Perhaps the closest parallel to the American Civil War in nineteenth-century Europe is the successful secession of Belgium from the kingdom of the Netherlands that occurred in the 1830s. It too radically changed alignments in the two separated kingdoms and, perhaps surprisingly, resulted in liberal constitutional reforms in both cases during the next two decades. There was, however, relatively little loss of life, although some military conflict did occur (see K ossman 1978, part IV).

20 See Miller (1991) for a discussion of the gradual spread of liberal political theory in eighteenthand nineteenth-century America. Miller argues that liberalism gradually replaced earlier traditional (communitarian) and Puritan (Calvinist) political theories. The American version of liberalism was influenced by these earlier theories and local traditions of direct democracy, as was true in some parts of Europe (Lutz 1983). Consider, for example, this quote from the beginning of Common Sense (1776) a widely read political tract by Thomas Paine: "This necessity, like a gravitating power, would soon form our newly arrived emigrants into society, the reciprocal blessing of which, would supersede, and render the obligations of law and government unnecessary while they remained perfectly just to each other; but as nothing but heaven is impregnable to vice, it will unavoidably happen, that in proportion as they surmount the first difficulties of emigration, which bound them together in a common cause, they will begin to relax in their duty and attachment to each other; and this remissness, will point out the necessity, of establishing some form of government to supply the defect of moral virtue." 
and livelihood changed for a majority of families. The use of increasingly costly, powerful, and productive steam engines in manufacturing, mining, and transport, together with organizational improvements, created new economies of scale in manufacturing and commerce. The new steam engines allowed manufacturing to take place farther from the banks of rivers than possible in the past. This was reinforced by rapid improvements in transportation, which reduced transaction costs and allowed both inputs and outputs to reach farms and factories further inland. Commercial networks expanded regionally, nationally, and globally. Specialization and human use of natural resources increased as trading networks expanded. Further economic development was stimulated in the late nineteenth century innovations in electricity and chemistry (Gordon 1999, Nye 1990).

In Europe, realizing the rewards of technological improvements that increased the efficient scale of production often required new laws to remove internal and external barriers to trade. Markets had to be enlarged to warrant investments in capital-intensive production, and changes in law that opened up internal and external markets were central to the policy agendas of manufacturers and importers. For example, tariff reduction remained a central policy issue for economic liberals in Europe for most of the nineteenth century. Their success was evident during the first half of the century, as tariffs fell throughout western Europe. International trade was less important for the United States, because free trade across state boundaries was guaranteed by the Constitution and the internal market was very large, although tariffs fell for the first half of the century in the United States, as in Europe. ${ }^{21}$

Population growth continued throughout the second half of the nineteenth century. Population growth in the United States reflected increases in arable land and improved farming technologies. These supported large families and also substantial (net) immigration from throughout Europe and subsequently A sia. Immigration was completely open during this period, and new immigrants could often vote before they were citizens. (Passports did not yet exist.) For the most part, these were economic emigrants who sought the opportunities that relatively open markets and abundant undeveloped land produced, although broader civil liberties also played a role at the margin. Emigrant neighborhoods were established in larger cities, and entire regions of states were often dominated by particular immigrant groups.

${ }^{21}$ U. S. tariffs rose in the second half, in part because tariff revenue was an important source of federal government revenues used to pay off debts accumulated during the Civil War (James 1981, table 4). 
Newspapers were published in dozens of languages. New cities and towns emerged in the West, and older ones expanded in the East.

Population growth was only possible because of a general increase in food output. Agricultural technologies improved substantially during the nineteenth century with the introduction of better seeds and plows, mechanization of planting and harvesting, and chemical fertilizers. These techniques together with rising demand from nonfarmers allowed larger, less fertile areas to be profitably cultivated, and farmland increased throughout the century. As in Europe, however, an increasing fraction of economic output (value added) in the United States was nonagricultural. Farm employment fell from 74.4 percent of employment in 1800 to 55.8 percent of total employment in 1860 to about 30.7 percent of total employment in $1910 .{ }^{22}$

New production techniques allowed entrepreneurs to profit by selling old products at lower prices than older smaller organizations could match. Economies of scale in manufacturing and innovation led to creation of very large and profitable enterprises "from scratch," as "self-made" men became millionaires. Toward the end of the nineteenth century many new factory-made products were introduced. As in Europe, intranational trade also expanded, because more complete and rapid transport networks were encouraged by government land grants and loans, as well as private investors. The resulting transport networks reduced transactions costs throughout the United States' domestic market (Taylor 1951, Wallis 2000). ${ }^{23}$

Urban population expanded more rapidly than did rural populations, which suggests that life in the city was becoming relatively more attractive. Economies of scale and increased specialization meant that more persons were employed to undertake narrow steps in more round-about production processes. Many of the steps were often organized in large firms based in specific locations. Urban life was systematically improving as new technologies were applied and wages rose. Urban sanitation and transportation improved. Central heating was introduced, followed by electricity, and telephones. People would not, of course, choose

22 See H istorical Statistics of the U nited State Volume 2, 2006, Table Ba-A, pg. 2-18. D uring the same period, clerical and manufacturing employment rose from negligible levels to approximately 34.9 percent of employment.

${ }_{23}$ There is some debate among economic historians about the extent to which improved transport networks contributed to economic growth (Fogel 1962, Fremdling 1977). However, it seems clear that reduced transport costs, improved information, and increased specialization tend to increase economic output (Gordon 1999, Buchanan and Yoon 1994). 
towns over farms unless real incomes and/ or other conditions were preferable to those in the countryside. Per capita (average) income was rising throughout this period. From 1870 through 1920, per capita income more than doubled, as population tripled. ${ }^{24}$

\section{Liberalism in the Nineteenth Century}

The liberal movement of nineteenth-century Europe was a relatively broad movement that included both economic and political agendas. Liberals pressed for a variety of reforms that jointly ended what remained of the medieval political and economic order. They, for example, included most abolitionists, democrats, and free traders during the first half of the nineteenth century. In Europe, left-of-center and right-of-center liberals often cooperated in their persuasive campaigns regarding trade and suffrage reform, also on electoral strategies. This was less common in the United States in the late nineteenth century, in part because the liberals already dominated the major political parties.

As major elements of the liberal agenda had for the most part been achieved by 1880 in the United States - trade liberalized, slavery abolished, equal protection of the law formally protected, public education extended, and essentially universal male suffrage - policy debate in the late nineteenth century increasingly tended to be among liberals, rather than between liberals and conservatives, that is to say between "pro-reform" progressives and "laissez-faire" liberals, who opposed further reform, but not a return to a class-based society. There was no perfect equivalent of Europe's nineteenth century conservatives in the United States, because there was no legally sanctioned birth-based aristocracy, established church, or ancient political institutions to defend. D isagreements among liberals, however, occurred on a wide variety of issues including trade, regulation, woman's suffrage, and social insurance.

Tension between left- and right-of-center liberals was often systematic, which is why such terms as liberal, radical, and progressive (social democratic) are useful for describing clusters of policy positions in Europe and North America during this period. For example, the Progressive movement and a short-lived political party of the same name can be thought of as the American equivalent of the Social D emocratic Movement (Party) in Europe. Progressives

24 Rising per capita income tends to be somewhat biased upward, as estimated in many economic studies. The increase in the volume of final traded goods reflects both the increase in economic output generated by improved technology and capital accumulation, and the substitution of trade for household production. The latter implies that estimated income growth rates are somewhat exaggerated; however, to the extent that persons could still choose to produce clothing and other goods at home but chose instead to use "store-bought" cloth and clothing implies that a net improvement in living standards was associated with this increased specialization. 
were not generally opposed to private property or markets, but for the most part were interested in "improving" market outcomes through institutional and regulatory reforms and by equalizing bargaining power. In my terminology, most progressives were "left-of-center" liberals, rather than "socialists," as was also true of moderate social democrats in Europe. 25

It is interesting to note that the "left-of-center" liberals (the progressives) retained the name "liberals" in the United States in the twentieth century, in contrast to Europe where the "right-of-center" liberals kept that political label. For much of the nineteenth century, the Republican Party represented left-of-center liberals and the D emocratic party right-of-center liberals, although this changed in the early twentieth century.

\section{Politically Active Interest Groups of the Nineteenth Century}

Many new politically active interest groups in the United States were formed in the late nineteenth century. These groups often had fairly narrow policy agendas (interests), although many of the groups had overlapping memberships. Newly organized economic interest groups included regional and national business associations, trusts, labor unions, and farmer cooperatives. Such groups mainly sought policy reforms that improved the economic well-being of their members (profits, wage rates, and working conditions). 0 ther interest groups had explicitly ideological and political agendas, such as the temperance and woman's suffrage movements. And some groups had economic and ideological agendas, as with many free-trade and labor movements. G roups lobbied for political and economic reforms as matters of personal economic interest and principle.

In general, the more likely lobbying groups are to play a decisive role in legislation, the wealthier are their members, and the larger are the expected gains; the more effort members of organized ideological and economic interest groups will invest to influence policy (Congleton 1991). Per capita income rose, economic interests often increased, and techniques for organizing large groups improved as specialization increased and the technology of

25 See, for example, (Prasch 1995, 1999): "What distinguished the economists associated with the Progressive movement from their forebears in the liberal tradition was not their concern for rules per se, rather it was their belief that a free market could be the locus of systematic economic power. They thought that the proximate cause of this power was unequal bargaining power between employers and individual laborers. It was their observation that labor was typically constrained by a lack of wealth. This simple fact, operating in conjunction with the need to feed oneself and one' $\mathrm{s}$ family, placed a distinct limit on the length of time that labor could "hold out" for a better wage bargain." 
communication improved. Consequently, economic and ideological interest group activity increased throughout the nineteenth century.

Ideological and economic interest groups often join forces to lobby for or against new policies and reforms; for example, labor and progressive groups often joined forces in the United States. In Europe such coalitions led to the formation of labor and social democratic political parties. In a polity with competitive elections based on broad suffrage, however, interest group activities tend to affect the platforms of existing major political parties. The Progressive Party did poorly in U. S. national elections, in large part because political competition induced the two major parties (D emocrats and Republicans) to adopt more progressive positions on many issues. ${ }^{26}$

\section{Changes in the Economic Constitution of the United States}

D uring the nineteenth century, there were several changes in what might be called the "economic constitution" of the United States — which paralleled those of the industrializing countries of Europe. A variety of adjustments were made in the rules that determined what is owned and how what is owned may be used without legal (or political) interference. ${ }^{27}$ Many of these adjustments were made shortly after independence was declared (Fiske 1888: 71), but many more were made in the second half of the nineteenth century. Industrialization required trade to become more open and property of all kinds to be more marketable and portable. Property rights concerning physical goods and services often became "individualized" and alienable, but they were also limited in new ways to take account of externalities and reduce monopoly power. ${ }^{28}$

${ }_{26}$ The Progressive Party was founded in 1912 by former Republican president Roosevelt, partly because he had failed to secure his party's nomination as their candidate for President (on a more or less progressive platform). Its base of support consisted largely of progressive Republicans and independents. Many of its proposed policies were similar to those of the early Social D emocratic Parties in Scandinavia, and the party did best in states where Scandinavian emigrants were large constituencies. In Minnesota, for example, the party received more votes than either of the mainstream parties. It ran second to the D emocrats in the nation as a whole on a platform calling for a six-day work week, and eight-hour day in manufacturing, and prohibition of child labor at ages below 16 years. See D avis (1964) for an analysis of the party's platform and support.

A People's Independent Party had previously been founded in 1892, which represented somewhat similar groups and interests and also drew much of its support from progressive Republicans. See, for example, Webb (1993) for a discussion of relationships between populists, progressives and progressive Republicans.

27 Several of the original 13 states had previously "privatized" land that had been in the control of the royal governors and proprietors after independence was declared (Fiske 1888, p. 71).

${ }^{28}$ Changes in property law were more obvious in Europe and Japan where medieval family-based 
The territory of the United States had expanded in the nineteenth century through the purchase of Louisiana (1803) and Alaska (1867). Other territories in the Southwest were won from Mexico during 1846-48. Most of this land was initially held by the central government. To promote development, methods for transferring ownership of large blocks of government land to individual families were devised and implemented, as with various "homestead" acts. Many of the changes were similar to those involved in the European enclosure acts, as new deeds were devised, roads and fences were built, and lands converted from commons to private pasture and cropland. ${ }^{29} \mathrm{As}$ in Europe, the rural landscape was transformed through this combination of legal reform and subsequent economic development.

Although the homestead acts encouraged people to move to the countryside, relatively more people were moving to cities than to the new farms, as noted above. The urbanization associated with the expansion of commerce and manufacturing generated new demands for public services and regulation. Demands for public services in cities increased with income, partly because government services are normal goods, partly because some services became relatively more valuable or less expensive, and partly because new services became available. Expenditures on local public services per capita increased sevenfold (Wallis 2000). For example, mass transit and public water systems expanded as towns grew into cities and as existing urban centers grew larger. Public education was also expanded (mostly by local and state governments as public school and state university systems were extended), and all levels of government subsidized infrastructure development in many ways.

At the federal level, the Morrill Acts of 1862 and 1890 transferred lands from the central government to the states as a method of funding new public universities to be focused on science, engineering, agriculture, and military science. Government grants of rights of way and other subsidies helped private turnpike, canal, and railroad companies create a more complete, rapid, and less expensive transport network.

privileges for particular occupations, products, and services finally disappeared as matters of law during the nineteenth century. D ebts often became individual, rather than family based, and land became freely bought and sold. However, it is clear that property and tort law changed in the United States as well. See, for example, Posner 2007.

${ }_{29}$ The various homestead acts, with their very favorable terms for land sales demonstrates that urbanization was voluntary in the United States, rather than the result of a shortage of farm land. In Europe, urbanization in the early nineteenth century is sometimes argued to be a consequence of privatization that evicted the landless, which induced them to move to cities as a last resort. Involuntary urbanization can occur as medieval rights to commons disappeared. However, even in Europe this was not always the case, because enclosure often increased demand for rural labor to create new pasture from wastelands, drain swamps, and build new roads and fences. 
Federalism, Ideology, Constitutional Law, and Economic Regulation

The increase in population densities and the size of firms, together with persuasive campaigns led by progressives, also led to significant electoral demand for increased regulation of economic organizations; new laws were adopted by many state and local governments. Economic theory, however, suggests that interstate mobility and externalities limit the ability of state governments to address effectively some of the problems that state electorates wanted addressed. Partly because of such problems and organized persuasive campaigns, there was a significant increase in interest group and electoral support for shifting some regulatory responsibilities to the central government.

Continuing debate about the proper extent of governmental regulation of market activities and the constitutionality of such "ideal" regulations was evident in newspapers and courts. The courts initially regarded much of the progressive legislation to be applications of federal and state authority not supported by their constitutions. Consequently, some of the new "progressive" economic regulations were initially blocked or weakened by decisions of state courts and by the U. S. Supreme Court.

The political and legal debates often hinged on right-of-center versus left-of-center liberal arguments for and against regulation. For example, the Supreme Court's Lockner decision and dissent of 1905 demonstrates that the split between right- and left-of-center liberals occurred in elite policy circles, as well as among politically active interest groups, political theorists, and editorial writers. ${ }^{30}$ The majority opinion favoring Lockner supports the "right-of-center" liberal argument favoring complete freedom of contract:

The general right to make a contract in relation to his business is part of the liberty protected by the Fourteenth Amendment, and this includes the right to purchase and sell labor, except as controlled by the State in the legitimate exercise of its police power.

Liberty of contract relating to labor includes both parties to it; the one has as much right to purchase as the other to sell labor. There is no reasonable ground, on the score of health, for interfering with the liberty of the person or the right of free contract, by determining the hours of labor, in the occupation of a baker. Nor can a law limiting such hours be justified a a health law to safeguard the public health, or the health of the individuals following that occupation...

30 Rehnquist, pg. 113-14 provides a short summary of "anti-progressive" Supreme Court decisions. 
. . . It is also urged, pursuing the same line of argument, that it is to the interest of the state that its population should be strong and robust, and therefore any legislation which may be said to tend to make people healthy must be valid as health laws, enacted under the police power. If this be a valid argument and a justification for this kind of legislation, it follows that the protection of the Federal Constitution from undue interference with liberty of person and freedom of contract is visionary, wherever the law is sought to be justified as a valid exercise of the police power. Scarcely any law but might find shelter under such assumptions, and conduct, properly so called, as well as contract, would come under the restrictive sway of the legislature...

The minority dissent by O liver Wendall Holmes develops the "progressive" argument, which supported government regulation of some contracts and gradually became the dominant opinion on the Supreme Court. ${ }^{31}$

This case is decided upon an economic theory which a large part of the country does not entertain. If it were a question whether I agreed with that theory, I should desire to study it further and long before making up my mind. But I do not conceive that to be my duty, because I strongly believe that my agreement or disagreement has nothing to do with the right of a majority to embody their opinions in law. It is settled by various decisions of this court that state constitutions and state laws may regulate life in many ways which we as legislators might think as injudicious, or if you like as tyrannical, as this, and which, equally with this, interfere with the liberty to contract.

Sunday laws and usury laws are ancient examples. A more modern one is the prohibition of lotteries. The liberty of the citizen to do as he likes so long as he does not interfere with the liberty of others to do the same, which has been a shibboleth for some well-known writers, is interfered with by school laws, by the post office, by every state or municipal institution which takes his money for purposes thought desirable, whether he likes it or not. The 14th Amendment does not enact Mr. Herbert Spencer's Social Statics.

In this manner, the policy debates between liberals and progressives became significant factors in American policy and legal debates over regulation at about the same time that similar conflict between liberals and labor movements emerged in Europe, although the debate on adult male suffrage in the United State was essentially over (outside the South) by this point.

Overall, the nineteenth century trend toward more liberal and open market-based production and consumption continued into the twentieth century - with freer (but not free) entry and trade possible throughout the nation and internationally- in conjunction with the expansion of government services and new national regulations that attempted to restrict

31 See, for example, Rehnquist 2001, p. 107, who argues that Lockner was wrongly decided. 
anticompetitive and fraudulent business practices. ${ }^{32}$ The persuasive campaigns undertaken by progressives, together with support from economically aligned interest groups, produced a series of new national laws that attempted to regulate large interstate firms and transactions. ${ }^{33}$ Examples include the Interstate Commerce Act, which regulated railroads (1887); the Sherman Antitrust laws, which regulated monopolies and other conspiracies to restrict open markets (1890); the Pure Food and D rug Act (1906), which created the Food and D rug Administration and provided for federal inspections of meat products and forbade poisonous patent medicines; the Federal Trade Commission Act (1914), which regulated "unfair methods of competition in or affecting commerce, and unfair or deceptive acts or practices . . ."; and the Clayton Antitrust Act (1914), which strengthened the Sherman Act and exempted nonprofit institutions and organized labor from antitrust proceedings.

\section{Left-of-Center Liberal Interest Groups and Constitutional Reform}

In addition to their effects on economic policy, the progressives also pursued several constitutional objectives. Just before the Civil War, a women's suffrage movement was organized, which gained members and support throughout the century (Keyssar 2000: ch. 6). The women's suffrage movement is part of the reason that the word "sex" was almost added to the Fifteenth A mendment, which ruled out legal discrimination on the basis of race (see Keyssar 2000: 178-79). The Fourteenth Amendment (which guaranteed "due process of law" and "equal protection of the laws" to all citizens) was used in legal challenges of suffrage laws that discriminated against women, but the challenges were unsuccessful, in part because the legislative history of the Fifteenth Amendment was well known. Nonetheless, the woman's suffrage movement became a broadly supported and well-organized mass movement during the late nineteenth century. In some states, support for women's suffrage was sufficiently broad for it to be adopted at state levels (Keyssar 2000: 203-06).

32 Preexisting civil law had also included provisions discouraging fraud and monopoly that failed to address the concerns of progressives. It bears noting that many of the new "progressive" policies were subsequently used by large firms as new methods of reducing competition, although this was clearly not what the reformers themselves had in mind.

33 Many voters were skeptical of the ethics of the new industrialists in general, or at least a significant subset of them, who were called "robber barons," although the new millionaires rarely resorted to obviously illegal behavior. (And also in spite of the fact that many of the new industrial millionaires-Carnegie, Rockefeller, Morgan, Edison, and Ford- established large charitable foundations with large endowments. See, for example, Johnson 1997: 536-60.) 
D uring approximately the same period, a "temperance" movement emerged that opposed alcohol abuse and lobbied for new laws restricting alcohol access, production, and consumption. An American Temperance Society was organized in 1826. The temperance problem was partly a consequence of the new urban lifestyle based on wages, rather than household production, and the movement gained membership and political support throughout the nineteenth century, as it did in Canada and Europe. Some of these organizations were international in scope, as with the "Independent O rder of G ood Templars." And, it was often the case that the temperance and women's suffrage movements had overlapping memberships. ${ }^{34}$

\section{Progressive Reforms of State Constitutions and the Bureaucracy}

A number of significant procedural changes in the fundamental procedures and structure of American governance occurred during the "progressive period" that in many ways paralleled those of Europe during this time. Progressive reforms occurred at all levels of government, which demonstrates continuing majority support (among those who could vote) for such reforms. Congleton (2004a) suggests that ideological shifts are necessary for producing significant suffrage reform, and these may be catalyzed by interest groups.

For example, 19 state constitutions added (or included) direct referenda and recall provisions, which allowed voters to decide specific issues, avoiding agency problems associated with representative systems of government. These were mostly adopted by new states in the West that received statehood after the Civil War, but several other states amended their state constitutions to allow such referenda. Direct democracy continued to be used in some New England towns throughout this period, although it had not formerly played a significant role in state governance. Various forms of the secret ballot were adopted by individual states. beginning with Massachusetts in 1888. Ballots were placed in official envelopes before being placed in ballot boxes, which allowed votes to be cast without fear of rebuke by their neighbors, landlords, and employers. ${ }^{35}$

34 A temperance society was founded in Ireland in 1829, in Sweden in 1837, in D enmark in 1840, and in Norway in 1845. Energetic temperance movements also emerged in G ermany and England. The temperance and woman's suffrage movements in Europe are less studied, because they operated in the political shadow of various men's suffrage movements. See Johnson (1997) and the Catholic E ncyclopedia on temperance movements.

35 Secret ballots were also known as the "Australian ballot," because the rules and ballots were heavily influenced by Australian reforms in the previous decade. Standard ballots were printed by government and distributed at voting places, although several exceptions existed (Ludington 1909). 
Bureaucracy was reformed to reduce political influence over career bureaucrats. For example, the Pendleton Act (1883) established the U. S. Civil Service Commission, which placed most federal employees on a "merit system," greatly reducing the extent to which political parties could determine jobs within the bureaucracy. After the Pendleton Act, only holders of the senior-most jobs in the U.S. bureaucracy were appointed by the President. Such "civil service" reform improves efficiency by increasing institutional memory and also reduces the incumbent's ability to use the bureaucracy in political campaigns for re-election, which tends to increase political competition and reduce corruption. To the extent that job-related skills are not highly correlated with partisan loyalty, merit based hiring also tends to increase competence and productivity.

The suffrage debate, as in Europe, remained centered on "who is qualified to vote?" or "who is a proper citizen?" as it had been since elected representation was first provided for "freeholders" in colonial times. In the United States, unlike Europe or Japan, continued debate about men's suffrage was overshadowed by the woman's suffrage movement. ${ }^{36}$ The progressives, as true of most mid-century liberals, were not uniformly in favor of universal suffrage (Keyssar 2000: 159). For example, Johnson (1997: 657) notes that the early suffragettes had initially favored enfranchisement of only qualified women. Support for broad women's suffrage increased throughout the nineteenth century, and their eventual success in pressing for reform of family and suffrage laws demonstrated that significant support for broader civil liberties and adult suffrage existed in much of the United States. ${ }^{37}$ After 1900 several states adopted women's suffrage reform, after decades of persuasive campaigns by "suffragettes" (Keyssar 2000: 208-12).

These state reforms and the subsequent adoption of the Nineteenth A mendment are consistent with the suffrage law equilibrium model of Congleton (2004a). In the absence of

The new ballots included a list of all candidates rather than favored candidates. Paper ballots had previously been used in several states. New Y ork and Vermont used paper ballots since independence. Heckelman (1995) notes that voter turnout fell as the secret ballot was adopted, which suggests that vote buying was diminished by the new voting rules.

36 In the United States, the men's suffrage debate occurred largely in the eighteenth century and first half of the nineteenth century, rather than in the second half of the nineteenth century as in Europe, although black suffrage and immigrant suffrage debates continued throughout the nineteenth and much of the twentieth century. The men's suffrage debate continued., but on a smaller scale. This was evidently not a sign of disinterest, but of the general success of previous efforts and disagreement about the final margins of suffrage: nonresidents, Indians, and criminals.

37 Keyssar (2000: 168-69), argues that support for universal suffrage had waned somewhat toward the end of the century, although it seems clear that support for woman's suffrage increased. 
ideological shifts (which may be induced by persuasive campaigns inside and outside government), suffrage law tends to be very stable, because the existing median voter tends to be quite happy with the policies adopted through the existing political institutions. A majority of male voters had gradually been persuaded that women were qualified to cast their own independent votes.

\section{The "Progressive" Reforms of the National Constitution}

Three major reforms and one minor reform of the Constitution were adopted between 1909 and 1920. All of these amendments, as true of those adopted in Europe during this same period, tended to "democratize" politics and extend the authority of elected legislatures.

The Sixteenth Amendment allowing income taxes was passed by Congress on July 2, 1909, and ratified by the required number of state legislatures on February 3, 1913:

The Congress shall have power to lay and collect taxes on incomes, from whatever sources derived, without apportionment among the several States, and without regard to any census or enumeration.

The Seventeenth Amendment provided for the direct election of senators and was passed by Congress on May 13, 1912, and ratified by the required number of state legislatures (many of which already used this procedure) on April 8, 1913:

The Senate of the United States shall be composed of two Senators from each State, elected by the people thereof, for six years; and each Senator shall have one vote. The electors in each State shall have the qualifications requisite for electors of the most numerous branch of the State Legislatures.

The Eighteenth Amendment prohibited liquor sales. It was passed by Congress on D ecember 18, 1917, and ratified by the required number of state legislatures on January 16, 1919. ${ }^{38}$ (This amendment was subsequently repealed by the Twenty-First A mendment in 1933.)

After one year from the ratification of this article the manufacture, sale, or transportation of intoxicating liquors within, the importation thereof into, or the exportation thereof from, the United States and all territory subject to the

38 Equally effective temperance movements were also active in Scandinavia during this same time period, and the result was also often "prohibition." For example: Norway, Finland, Iceland, and Russia did go through periods of prohibition at about the same time as in the United States. The Swedes transferred all sales to state stores and regulated consumption through a coupon system. It can be argued that the Eighteenth Amendment is really a policy matter, rather than a constitutional matter, although a constitutional amendment was required to put this particular policy in place because the regulation of alcohol sales and production was considered to be a state responsibility. 
jurisdiction thereof for beverage purposes is hereby prohibited. The Congress and the several States shall have concurrent power to enforce this article by appropriate legislation.

Holcombe and Lacombe (1998) provide statistical evidence that the pattern of support for the Sixteenth and Seventeenth Amendments reflects state interests as represented in state legislatures. Relatively low-income states favored the income tax, and states that had already adopted direct election of senators favored the new method of organizing the Senate.

The Seventeenth and Eighteenth Amendments were modest relative to the constitutional reforms adopted in Europe during the early twentieth century, but they also significantly altered the structure and resources of the national government. By changing the electoral basis of the Senate, the central government became a less "federal" system of government. No longer were state government interests in preserving state authority directly represented in the national government. On the other hand, Senate voters were not subject to manipulation in the manner that House voters were, because states could not be "gerrymandered." Thus, state results tend to be a more "honest" representation of state voter interests than congressional district elections.

The federal government had relied entirely on excise taxes and tariffs for its revenues before 1913 (with a short exception during the Civil War), because the constitution forbade direct federal taxes- taxes borne directly by individuals. Although the income tax was initially limited to the very wealthiest, it was gradually expanded to include most persons. Essentially all contemporary central government (federal) tax revenues in the United States are income taxes: the personal income tax, corporate income tax, and payroll tax (which funds Social Security and Medicare). Income is a much larger tax base than "sin taxes" and tariffs and thus potentially can support a much larger central government.

The Nineteenth Amendment added adult women to the electorate throughout the country. It was passed by Congress on June 4, 1919, and ratified by the requisite number of states on August 18, 1920.

The right of citizens of the United States to vote shall not be denied or abridged by the United States or by any State on account of sex. Congress shall have power to enforce this article by appropriate legislation.

The Nineteenth A mendment, as was true of woman's suffrage laws in Europe, extended the logic of "qualified voters" to women. 
Berman's (1987) empirical work based on voting patterns in Western states and McD onagh and Price's (1985) work on Midwestern states and California support the hypothesis that ideological considerations played a significant role in male support of women's enfranchisement (votes for Progressives and against Democrats). Both studies also demonstrate that support for women's suffrage among male voters was linked to other policy agendas - in particular prohibition - which is consistent with an ideological model of suffrage reform. In no case were women a serious revolutionary threat. Woman's suffrage was adopted throughout northern Europe at about the same time. What is unusual about the U. S. case is the long gap between the major male suffrage reforms: the Fifteenth Amendment passed in 1869 and the Nineteenth Amendment passed in 1919.

Together, the Sixteenth, Seventeenth, and Nineteenth A mendments removed earlier constitutional constraints on the size of the central government and increased the demand for central government services. The Nineteenth Amendment did not change a fundamental procedure or constraint, but did change the median voter. ${ }^{39}$ These were fundamental reforms, whose effects could clearly be seen in central government expenditures. Indeed, the "progressive amendments" could be said to be the first truly fundamental reforms of American political procedures and constraints since the Bill of Rights amendments were ratified in 1791.

The progressive amendments indirectly affected both the relative and absolute size of the central government for the next eight decades. Per capita central government expenditures had been low and relatively stable in the previous 120 years and began to accelerate shortly after the progressive reforms were adopted. State and local governments had been the main sources of public services in the years before the "progressive amendments," but this also changed in the next few decades. O ther factors were also significant; for example, during and after the great depression and World War II, the central government began centralizing responsibilities for social security and welfare and took a more active military role in world affairs. However, without the income tax and change in the manner in which senators were chosen, the required legislation would have been more difficult to adopt and fund.

39 There is evidence that woman's suffrage produced a new median voter with a higher demand for social insurance than the previous one (see Lott and Kenny 1999). 


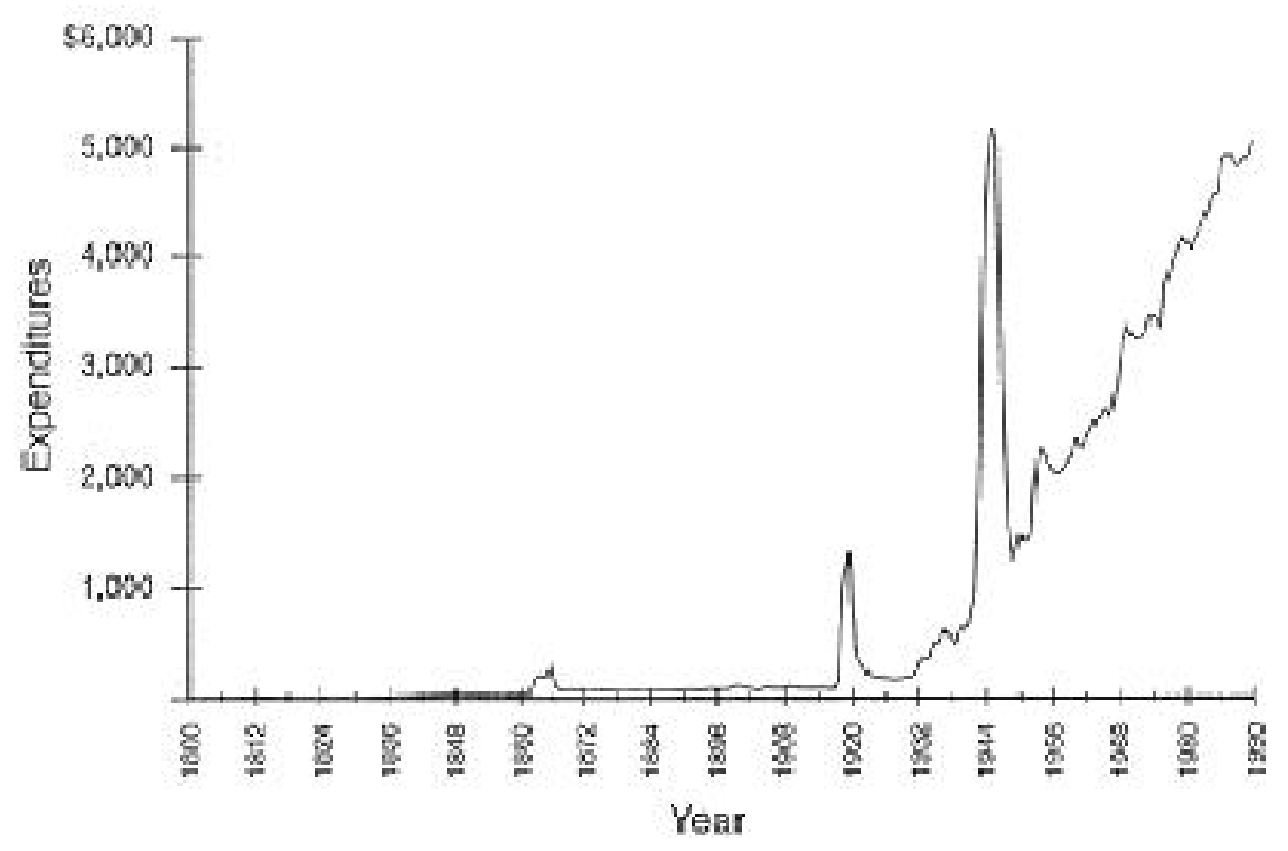

\section{Conclusion: Summary and Extensions}

With the adoption of woman's suffrage, the United States could be said to have completed a 300-year-long transition to constitutional democracy. It was a transition marked by revolution and war, but it was rarely motivated by military events. External threats catalyzed the formation of a national government in 1776, but its constitution(s) reflected the previous century and a half of constitutional experimentation among colonial governments. The importance of commercial interests, industrialization, and ideology in this process is clearly evident throughout its history, which is consistent with a theory of constitutional bargaining that stresses changes in the interests of those with the authority to alter constitutional law, rather than revolutionary threats or severe crisis.

In the American case, the rise of parliaments occurred for the most part in colonial legislatures well before independence and well before universal suffrage. This part of the transition reflected constitutional bargaining opportunities between colonial governors and their parliaments (the colonial "king and councils") in circumstances in which labor was scarce and mobile. Suffrage, as in much of Europe, was extended to all adults well after parliaments had substantial authority over public policy, although it was relatively broad even in the colonial period. The transition to universal suffrage took nearly 300 years (350 if suffrage restraints in the South are taken into account ${ }^{40}$ ). And although woman's suffrage was adopted 40 Suffrage was not finally extended to poor whites and former slaves in the South until the late 
within two decades, for the most part, male suffrage was extended slowly. Suffrage was gradually extended to white men, former slaves, and women. There were significant periods in which suffrage was subsequently restricted in all three groups, although the long-run trend was toward expansion. Suffrage reform was driven, for the most part, by changes in the norms that determined "proper qualifications" for exercising suffrage and partisan advantage. Even the paper ballot was gradually introduced and reformed during much of the nineteenth century. ${ }^{41}$

The civil war allowed amendments to be passed that settled constitutional issues that had existed for a century, but did not substantially change governmental procedures, although they did extend suffrage and equal protection of the law throughout much of the United States. Enfranchisement of former slaves in the Southeastern United States was imposed by northern majorities on unwilling southern states after the civil war, and subsequently reinforced by civil rights legislation adopted in 1960s.

The parallels between reforms in the United States and in Europe are most striking toward the end of this process, as secret ballots were introduced, bureaucracy was professionalized, and woman suffrage adopted. D uring their respective transitions, the power of parliament was gradually increased, suffrage gradually expanded, civil liberties were generalized, internal and external trade was liberalized, slavery was ended, and public education made more uniformly available. Most steps in most Western transitions to liberal democracy were relatively small and lawfully adopted, although even small changes in institutions can significantly affect public policy (Congleton and Swedenborg 2006). In this, the United States does not differ from Europe, although its early institutions and some subsequent bargains differ somewhat from those of Europe. Modern constitutional democracy in the United States emerged at last at about the same time in the United States, as in Europe, shortly before or after World War I. The gap between adult male and woman's

1960s, although both groups had briefly been free to vote in national and state elections after the civil war. Before the civil rights acts, blacks and poor whites in the Southern states often had a very difficult time casting votes, although similar claims could be made about the latter for some European countries in the years between 1925 and 1960. (For example, persons on welfare were often ineligible to vote even after "universal" adult suffrage was achieved in D enmark and Sweden.) ${ }^{41}$ Ballot design, perhaps surprisingly, continues to be controversial in the United States today. After the 2000 election for President, many significant changes in ballot design and counting were suggested, and a few were implemented. See for example, Agresti and Presnell (2002) for a careful analysis of the effects on ballot design on the distribution of votes in Palm Beach county Florida. The "Help America Vote Act" was passed by Congress and accepted by the President in 2002. 
suffrage simply affirms the lack of a slippery slope to universal suffrage (Keyssar 2000, Congleton 2004a).

The evolutionary basis of the constitution that frames the modern United States of America is evident in its essential template for governance, which extends back to early colonial times and in the long series of reforms adopted in the course of its constitutional development. The contemporary distribution of policymaking authority within the national government of the United States reflects the colonial experience and two centuries of subsequent constitutional bargaining among the President, the Congress, and the states. 


\section{References}

Acemoglu, D . and Robinson, J. (2000) "Why D id the West Extend the Franchise? D emocracy, Inequality, and G rowth in Historical Perspective," Q uarterly Journal of E conomic 115: 1167-99.

Agresti, A and Presnell, B. (2002) "Misvotes, Undervotes, and Overvotes: The 2000 Presidential Election in Florida," Statistical Scienœ 17: 436-40.

Berman, D . R. (1987) "Male Support for Woman Suffrage: An Analysis of Voting Patterns in the Mountain West," Social Science H istory 11: 281-94.

Benjamin, G. (1985) "The Diffusion of Executive Power in American State Constitutions: Tenure and Tenure Limitations," Publius 15: 71-84.

Buchanan, J. M. and Y. Y oon Eds. (1994) The Return to Increasing Return, Ann Arbor: University of Michigan Press.

Congleton, R. D . (1991) "Ideological Conviction and Persuasion in the Rent-Seeking Society," Journal of Public E conomics 44: 65-86.

Congleton, R. D . (2001) "On the Durability of King and Council: The Continuum Between Dictatorship and Democracy," Constitutional Political E conomy 12: 193-215.

Congleton, R. D . (2003) Improving D emocracy through C onstitutional Reform: Some Swedish L essons. D ordrecht: Kluwer Academic Press.

Congleton, R. D. (2004a) “Economic D evelopment and D emocracy, D oes Industrialization Lead to Universal Suffrage?" H omo E conomiaus 21: 283-311.

Congleton, R. D . (2004b) " "Mutual Advantages of Coercion and Exit within Private Clubs and Treaty O rganizations: Toward a Logic of Voluntary Association," Revista de Political E conomy (2004):49-78. (Published in 2005)

Congleton, R. D. (2006) "Constitutional Exchange in Japan: from Shogunate to Parliamentary D emocracy," Public Choice Studies 47 (2006): 5-29.

Congleton, R. D . (2007) "From Royal to Parliamentary Rule without Revolution, the Economics of Constitutional Exchange within Divided G overnments," E uropean Journal of Political E conomy 23: 261-84.

Congleton, R. D . (2007b) "Informational Limits to Democratic Public Policy: The Jury Theorem, Yardstick Competition, and Ignorance," Public Choice 132: 333-52.

Congleton, R. D., A. Kyriacou and J. Bacaria (2003) "A Theory of Menu Federalism: D ecentralization by Political Agreement," C onstitutional Political E conomy 14 (2003):167-90.

Congleton, R. D. and B. Swedenborg, Eds. (2006) D emocratic C onstitutional D esign and Public Policy: A nalysis and E vidence. Cambridge, Mass.: MIT Press.

Farber, D . (2003) L incoln's Constitution. Chicago: University of Chicago Press. 
Fiske, J. (1888) The Critical Period of A merican H istory 1783-1789. New York: Houghton, Mifflin.

Fogel, R. W. (1962) "A Q uantitative Approach to the Study of Railroads in American Economic Growth: A Report of Some Preliminary Findings," Journal of E conomic H istory 22: 163-97.

Fremdling, R. (1977) "Railroads and G erman Economic Growth: A Leading Sector Analysis with a Comparison to the United States and G reat Britain," Journal of $\mathrm{E}$ conomic H istory 37: 583-604.

Galenson, D. W. (1986) Traders, Planters, and Slaves: M ark et Behavior in E arly E nglish A merica. Cambridge: Cambridge University Press.

Gordon, R. J. (1999) “U. S. Economic Growth since 1870: O ne Big Wave?” A merican E conomic Review 89: 123-28.

Gould, A. C. (1999) O rigins of L iberal D ominanoe: State, Church and Party in N ineteenth C entury E urope. Ann Arbor: University of Michigan Press.

Haffenden, P. S. (1958) "The Crown and the Colonial Charters, 1675-1688: Part II," William and Mary Q uarterly 15: 452-66.

Heckelman, J. C. (1995) "The Effect of the Secret Ballot on Voter Turnout Rates," Public C hoice 82: 107-124.

Holcombe, A. N. (1916) State G overnments of the U nited States. New Y ork: Macmillan.

Holcombe, R. G. and D. J. Lacombe (1998) "Interests versus Ideology in the Ratification of the 16th and 17th Amendments," E conomics and Politics 10: 143-60.

James, J. A. (1981) "The O ptimum Tariff in the Antebellum United States," A merican E conomic Review 71: 726-34.

Keyssar, A. (2000) The Right to V ote, the C ontested H istory of D emocracy in the U nited States. New Y ork: Basic Books.

Keefer, P. and S. Knack (1995) "Institutions and Economic Performance: Cross-Country Tests Using Alternative Institutional Measures," E conomics and Politics 7: 207-27.

Kossman, E. H. (1978) The L ow Countries, 1780-1940. Oxford: Clarendon Press.

Lijphart, A. (1968) The Politics of A commodation: Pluralism and D emocracy in the N etherlands. Berkeley: University of California Press.

Lott, J. R. and L. W. Kenny (1999) "Did Women's Suffrage Change the Size and Scope of G overnment?" Journal of Political E conomy 107: 1163-98.

Ludington, A. (1909) "Present Status of Ballot Laws in the United States," A merican Political Scienœ R eview 3: 252-61.

Lutz, D. S. (1998) Colonial O rigins of the A merican Constitution: A D ocumentary H istory. Indianapolis: Liberty Fund. 
Lutz, D. S. (1983) A merican Political W riting D uring the F ounding E ra, 1760-1805. Indianapolis: Libery Press.

McLean, I. (2001) Rational Choice and British Politics, A n A nalysis of Rhetoric and manipulation from Peel to Blair. O xford: O xford University Press.

McLean, I. (2004) 'Thomas Jefferson, John Adams, and the Déclaration des D roits de l' et du Citoyen," working paper, Oxford University.

McD onagh, E. L. and H. D. Price (1985) "Woman Suffrage in the Progressive Era: Patterns of Opposition and Support in Referenda Voting," A merican Political Science Review 79: 415-35.

Miller, J. (1991) The Rise and Fall of D emocracy in E arly A merica, 1630-1798. University Park: Pennsylvania State University Press.

North, D . C. (1987) "Institutions, Transactions Costs and Economic G rowth." E conomic Inquiry $25,419-28$.

North, D . and Weingast B (1989) "Constitutions and Commitment: the Evolution of Institutions G overning Public Choice in Seventeenth Century England," Journal of E conomic H istory 49: 803-815.

Nye, D . E. (1990) E lectrifying A merica: Social M eanings of a N ew Technology. Cambridge: MIT Press.

Olson, M. and M. C. McGuire (1996) "The Economics of Autocracy and Majority Rule: The Invisible Hand and the Use of Force," Journal of E conomic L iterature 34: 72-96

O sgood, H. L. (1902) "England and the American Colonies in the Seventeenth Century," Political Scienœ Q uarterly 17: 206-22.

Palmer, R. R. (1969) The A ge of D emocratic Revolution: A Political H istory of $\mathrm{E}$ urope and A merica, 1760-1800. Princeton: Princeton University Press.

Pmeranz, K. (2000) The G reat D ivergence: china E urope and the Making of the M odern W orld E conomy. Princeton: Princeton University Press.

Posner, R. A. (2007) E conomic A nalysis of L aw, 5th Edition. Amsterdam: Wolters Kluwer.

Qian, Y. And B. R. Weingast (1997) "Federalism as a Commitment to Preserving Market Incentives," Journal of E conomic Perspectives 11: 83-92.

Rasch, B. E. and R. D. Congleton (2006) "Amendment Procedures and Constitutional Stability," in D emocratic C onstitutional D esign and Public Policy: A nalysis and E vidence, (R. D. Congleton and B. Swedenborg, Eds.) Cambridge Mass: MIT Press, pp. 319-42.

Rehnquist, W. H. (2001) The Supreme C ourt. New Y ork: Alfred A. Knopf.

Salmon, E. J. and E. D . C. Cambell (1994) The H ornbook of V irginia H istory, 4th E d. Richmond: Library of Virginia. 
Schonhardt-Bailey, C. (2003) "Ideology, Party, and Interests in the British Parliament of 1841-47," British Journal of Political Science 33: 581-605.

Sutch, R. and S. B. Carter (2006) H istorical Statistics of the U nited States, Volumes 1-5. Cambridge: Cambridge University Press.

Taylor, A. (2001) A merican Colonies, the Settling of N orth A merica. New York: Penguin Books.

Taylor, G. R. (1951) The Transportation Revolution, 1815-1860. New Y ork: Rinehart.

Thorpe, F. N. Ed. (1909) The F ederal and State C onstitutions $\mathrm{C}$ olonial Charters, and 0 ther 0 rganic L aws of the States, T erritories, and Colonies $\mathrm{N}$ ow or $\mathrm{H}$ eretofore $\mathrm{F}$ orming the U nited States of A merica Washington, D.C. : Government Printing Office (compiled and edited under an Act of Congress adopted on June 30, 1906.)

Tilly, C. (2004) C ontention and D emocracy in E urope, 1650-2000. Cambridge: Cambridge University Press.

Turner, L. D . (1929) "The Anti-Slavery Movement Prior to the Abolition of the African Slave Trade (1641-1808)," Journal of N egro H istory 4: 372-402.

Wallis, J. J. (2000) "American Government Finance in the Long Run: 1790 to 1990," The Journal of Economic Perspectives 14: 61-82.

Webb, S. L. (1993) "From Independents to Populists to Progressive Republicans: The Case of Chilton County Alabama, 1880-1920," Journal of Southern H istory 59: 707-36. 